\title{
ANALYSIS OF PRINCIPAL'S ACADEMIC SUPERVISION AND TEACHER'S WORK MOTIVATION TOWARD THE PERFORMANCE OF STATE ELEMENTARY SCHOOL TEACHERS IN UNDAAN DISTRICT KUDUS REGENCY
}

\author{
Kholid $^{1}$, Su'ad $^{2}$, dan Achmad Hilal Madjdi ${ }^{3}$ \\ ${ }^{1}$ SD 2 Medini, Kec. Undaan Kab. Kudus, ${ }^{2,3}$ Magister Pendidikan Dasar Universitas Muria Kudus \\ Email: kholidoik@gmail.com, suadfadlan@gmail.com, achmad.hilal@umk.ac.id
}

\begin{tabular}{l}
\hline Info Artikel \\
\hline \\
Sejarah Artikel: \\
Diserahkan 12 April 2020 \\
Direvisi 18 April 2020 \\
Direvisi 7 Mei 2020 \\
Disetujui 15 Mei 2020 \\
\hline
\end{tabular}

Keywords:

principal's academic supervision,

teacher's work motivation,

teacher performance

\begin{abstract}
The objective of this study was to analyze the principal's academic supervision and teacher's work motivation toward the performance state elementary school teachers in Undaan District, Kudus Regency.

This research is correlational research with a quantitative approach. The independent variables determined were the principal's academic supervision and teacher's work motivation, while the dependent variable observed was teacher performance. The study was conducted in 33 state elementary schools in Undaan district, Kudus Regency with a sample of 181 respondents. Data collection techniques in this study used interviews, questionnaires, and documentation. Data analysis was performed statistically using descriptive statistical analysis, prerequisite analysis, and final analysis for hypothesis testing.

The results of the study found that (1) the principal's academic supervision has a significant effect of $10.10 \%$ toward the performance state elementary school teachers in Undaan District, Kudus Regency; (2) the teacher's work motivation has a significant effect of $37.40 \%$ toward the performance state elementary school teachers in Undaan District, Kudus Regency; and (3) the principal's academic supervision and teacher's work motivation has a significant effect of $38.40 \%$ toward the performance state elementary school teachers in Undaan District, Kudus Regency.
\end{abstract}

\begin{abstract}
Abstrak
Tujuan penelitian ini untuk menganalisis supervisi akademik kepala sekolah dan motivasi kerja guru terhadap kinerja guru SD Negeri di Kecamatan Undaan, Kabupaten Kudus. Penelitian ini merupakan penelitian kolerasional dengan pendekatan kuantitatif. Variabel bebas yang ditentukan adalah supervisi akademik kepala sekolah dan motivasi kerja guru, sedangkan variabel terikat yang diamati adalah kinerja guru. Penelitian dilakukan di 33 SD Negeri se-kecamatan Undaan, Kabupaten Kudus dengan sampel sebanyak 181 responden. Teknik pengumpulan data pada penelitian ini menggunakan wawancara, angket, dan dokumentasi. Analisis data dilakukan secara statistik menggunakan analisis statistik deskriptif dan analisis akhir untuk pengujian hipotesis.

Hasil penelitian menemukan bahwa (1) supervisi akademik kepala sekolah berpengaruh signifikan sebesar 10,10\% terhadap kinerja guru SD Negeri di Kecamatan Undaan, Kabupaten Kudus; (2) motivasi kerja guru berpengaruh signifikan sebesar 37,40\% terhadap kinerja guru SD Negeri di Kecamatan Undaan, Kabupaten Kudus; dan (3) supervisi akademik kepala sekolah dan motivasi kerja guru berpengaruh signifikan sebesar 38,40\% terhadap kinerja guru SD Negeri di Kecamatan Undaan, Kabupaten Kudus.
\end{abstract}


Kholid, Su'ad, dan Achmad Hilal Madjdi

ANALYSIS OF PRINCIPAL'S ACADEMIC SUPERVISION AND TEACHER'S WORK ...

REFLEKSI EDUKATIKA : Jurnal Ilmiah Kependidikan, Volume 10, Nomor 2, Juni 2020, hlm. 257-266

\section{INTRODUCTION}

Elementary School (SD) is an important educational institution in the National Education System. The Law of the Republic of Indonesia, Number 20 Year 2003 categorizes elementary schools as education units that carry out education in the formal pathway, namely a structured and tiered education pathway consisting of basic education, secondary education, and higher education.

Education in elementary school has a very important strategic role and position, both in the process of children's education itself and in the context of realizing the National Education System. The elementary school organizes the earliest formal education to provide the foundation needed for further education level.

The implementation of academic supervision is often found to only be done formally to fulfill the reporting requirements of supervision. Principals tend to assess the structural conditions and completeness of documents only, without the right approach, long-term aspects of sustainability, detailed examination, and based on the problem at hand (Ugurlu, 2014). Another problem that often arises is the lack of school supervisory supervision competency. The principal lacks the ability to use a variety of techniques and supervision strategies. Training and seminars on supervision for principals are often held, but mostly they carry out supervision activities when instructed only or do not carry out supervision activities as they should (Iroegbu and Etudor-Eyo, 2016).

The other factor that considered to be able to increase the success of education in elementary schools is teacher's work motivation. Motivated teachers will always work well and continuously push themselves to develop. Work motivation provides a driving force that is able to bring one's passion to work, work together, and work effectively to achieve goals (Hasibuan, 2014). There are various forms of teacher's work motivation, such as salary, incentives, promotions, social status, morals, and commitment. Teacher's work motivation is considered to have an effect on student achievement and quality of education in schools because with high work motivation will encourage teachers to show maximum performance (Nyam and William-west, 2014; Sulisworo et al., 2017:).
Teacher performance is the ability demonstrated by a teacher in carrying out their duties to achieve planned goals. There are various factors that affect teacher performance, both internal and external. Internal factors are determined by the ability and teaching skills as well as work motivation. External factors can be physical such as the location of the school, the condition of the school building, and the cleanliness of the school environment, as well as social relationships among teachers, school culture, and leadership of the school principal (Madjid, 2016).

The main problem of teacher performance is that there are still teachers who are negligent and tend to be careless in carrying out learning tasks, just spending time at school, and not in an orderly manner and time. These various obstacles can hamper teacher performance in carrying out their duties and responsibilities. Therefore, it is important for each teacher to internally improve their performance and externally supervise through supervision (Yousaf et al. 2018).

Principal's Academic Supervision activities are needed to oversee the competence of a teacher. However, a competent teacher cannot be said to have a good performance yet. Teacher performance is a combined result of teacher competence and motivation. This research was conducted to determine the relationship of these two factors on teacher performance. The external factor studied was the principal's supervision, while the internal factor under study was the teacher's work motivation.

This research is expected to be able to provide an overview of the relationship between principal's academic supervision and teacher's work motivation toward the performance of state elementary school teachers in Undaan District, Kudus Regency. Thus, the objective of this study was to analyze the principal's academic supervision and teacher's work motivation toward the performance state elementary school teachers in Undaan District, Kudus Regency.

\section{METHODS}

This research was correlational research with a quantitative approach. The independent variables determined were the principal's academic supervision and teacher's work motivation, while the dependent variable 
observed was teacher performance. The study was conducted in 33 state elementary schools in Undaan district, Kudus Regency with a sample of 181 respondents. Analysis of the data used is a descriptive analysis of percentages and partial and multiple linear regression analysis.

Data collection techniques in this study used interviews, questionnaires, and documentation. The interview technique was using an unstructured interview to get preliminary data. Interviews conducted to three school principals and elementary school teachers in Undaan District, Kudus Regency. Questionnaires were given to respondents to collect data on the principals' academic supervision, teacher's work motivation, and performance of state elementary school teachers in Undaan District, Kudus Regency. Documentation was carried out to be used as additional data.

The main instrument of this study was a list of interview questions and a set of questionnaires. Interview questions were arranged to find out respondents' knowledge and opinions on the principal's academic supervision, teacher's work motivation, and teacher performance. The questionnaire was a closed questionnaire using a Likert Scale with 5 answer choices for each item. The questionnaire was compiled by setting a number of indicator variables, shown in Table 1.

Table 1. Research Variables and Indicators

Variable

Indicator

1. The planning of academic supervision programs

2. The implementation of academic supervision programs

Principals' Academic Supervision

3. The follow-up/evaluation of the results of academic supervision

(Astracted from Regulation of Minister of

National Education Number 13 Year 2007)

1. The responsibility of teachers in carrying out their duty

Teacher's Work Motivation

2. Achievements

3. Self-development

4. Independency in taking action

(Astracted from Uno, 2016)

1. Learning Implementation Plan (RPP)

2. Learning procedures and interpersonal relationships

Teacher Performance

3. Learning evaluation/assessment

(Astracted from Teacher Performance Assessment

Tool compiled by the Department of National

Education)

All data from the questionnaire were analyzed to determine the effect of the results of the independent variables toward the results of the dependent variable. Data analysis was performed statistically using descriptive statistical analysis, prerequisite analysis, and final analysis for hypothesis testing. Descriptive statistical analysis was performed using descriptive analysis of percentages. The prerequisite analysis was performed using normality and linearity data tests.

The final analysis for hypothesis testing is performed using inter-variable correlation analysis, simple linear regression and multiple linear regression analysis, t-test for partial hypotheses, and F test for the simultaneous hypothesis. Statistical data analysis was performed using SPSS Statistics v.25.2017.

\section{RESULTS AND DISCUSSION}

The main data comes from the results of the answers to the questionnaire that was filled in by respondents. Questionnaire data was collected and tabulated based on each variable. The principals' academic supervision variable has 15 items with the lowest total score of 39 
Kholid, Su'ad, dan Achmad Hilal Madjdi

ANALYSIS OF PRINCIPAL'S ACADEMIC SUPERVISION AND TEACHER'S WORK ...

REFLEKSI EDUKATIKA : Jurnal Ilmiah Kependidikan, Volume 10, Nomor 2, Juni 2020, hlm. 257-266

and the highest is 75 , which total score data is shown in Figure 1a. The teacher's work motivation variable has 18 items with the lowest total score of 54 and the highest is 86, in which total score data is shown in Figure $1 \mathrm{~b}$. The teacher performance variable has a number of items 15 questions with the lowest total score of 48 and the highest score of 75 , in which total score data is shown in Figure 1c.

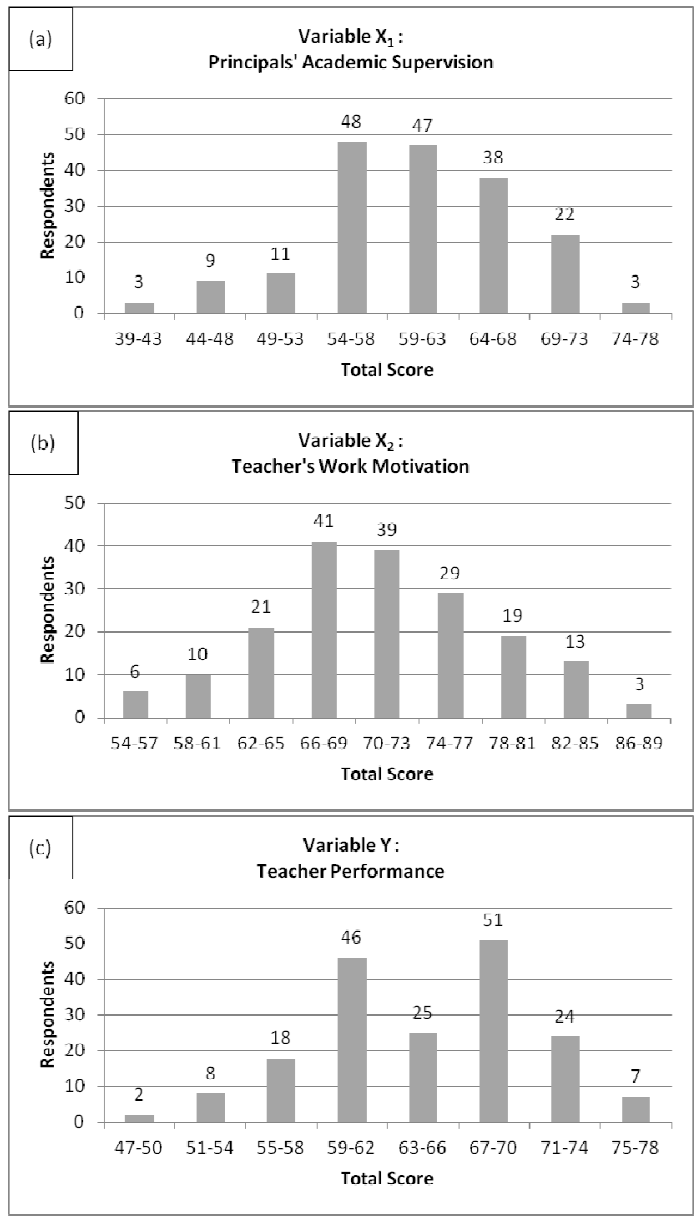

Figure 1. Total Score Data of All Variables; (a) Principals' Academic Supervision Variable; (b) Teacher's Work Motivation Variable; (c) Teacher Performance Variable

The value of central tendencies from all variables, which include mean, median, mode, variance, and standard deviation, is shown in Table 2.
Table 2. The Value of Central Tendencies

\begin{tabular}{|l|c|c|c|}
\hline \multicolumn{1}{|c|}{ Central Tendencies } & Variable $\mathrm{X}_{\mathbf{1}}$ & Variable $\mathrm{X}_{\mathbf{2}}$ & Variable Y \\
\hline Mean & 60,50 & 71,08 & 64,63 \\
\hline Median & 60,57 & 70,78 & 65,14 \\
\hline Mode & 58,37 & 69,14 & 67,46 \\
\hline Variance & 51,70 & 51,47 & 38,38 \\
\hline Standard Deviation & 7,19 & 7,17 & 6,20 \\
\hline
\end{tabular}

Descriptive Analysis of Percentages and Prerequisite Analysis. The calculation result of descriptive analysis of percentages is shown in Table 3.

Table 3. The Calculation Result of Descriptive Analysis of Percentages

\begin{tabular}{|c|c|c|c|c|c|c|c|}
\hline \multirow{2}{*}{ Range } & \multirow{2}{*}{ Level } & \multicolumn{2}{|c|}{ Variable $\mathbf{X}_{\mathbf{1}}$} & \multicolumn{2}{c|}{ Variable $\mathbf{X}_{\mathbf{2}}$} & \multicolumn{2}{c|}{ Variable $\mathbf{Y}$} \\
\cline { 3 - 8 } & & Quantity & $\mathbf{0}$ & Quantity & $\mathbf{\%}$ & Quantity & $\mathbf{0}$ \\
\hline $81 \%-100 \%$ & Very High & 86 & $47,51 \%$ & 74 & $40,88 \%$ & 120 & $66,30 \%$ \\
\hline $61 \%-80 \%$ & High & 89 & $49,17 \%$ & 106 & $58,56 \%$ & 61 & $33,70 \%$ \\
\hline $41 \%-60 \%$ & Moderate & 6 & $3,31 \%$ & 1 & $0,55 \%$ & 0 & $0,00 \%$ \\
\hline $21 \%-40 \%$ & Low & 0 & $0,00 \%$ & 0 & $0,00 \%$ & 0 & $0,00 \%$ \\
\hline $0 \%-20 \%$ & Very Low & 0 & $0,00 \%$ & 0 & $0,00 \%$ & 0 & $0,00 \%$ \\
\hline Total & & $\mathbf{1 8 1}$ & $\mathbf{1 0 0} \%$ & $\mathbf{1 8 1}$ & $\mathbf{1 0 0 \%}$ & $\mathbf{1 8 1}$ & $\mathbf{1 0 0 \%}$ \\
\hline
\end{tabular}

The calculation result of descriptive analysis of percentage in Table 2 shows that the total score of the answers to the questionnaire variable of the principal's academic supervision and teacher's work motivation are, both, at a very high percentage descriptive level $(81 \%-100 \%)$, high $(61 \%-80$ $\%)$, and moderate $(41 \%-60 \%)$. Meanwhile, the total score of the questionnaire answers to teacher performance variables is at a very high percentage descriptive level $(81 \%-100 \%)$, and high $(61 \%-80 \%)$.

The prerequisite analysis was performed using normality and linearity data tests. The calculation result of normality test is shown in Table 4.

Table 4. The Calculation Result of Normality Test

Tests of Normality
\begin{tabular}{|c|c|c|c|}
\hline & \multicolumn{3}{|c|}{ Kolmogorov-Smirnov } \\
\cline { 2 - 4 } & Statistic & df & Sig. \\
\hline Supervisi Akademik Kepala Sekolah $(\mathrm{X} 1)$ & 0,065 & 178 & $\mathbf{0 , 0 6 1}$ \\
\hline Motivasi Kerja Guru $(\mathrm{X} 2)$ & 0,046 & 178 & $\mathbf{0 , 2 0 0 ^ { * }}$ \\
\hline
\end{tabular}

*. This is a lower bound of the true significance.

The significance value of Asymp. Sig. (2-tailed) shows a value >0.05. Thus, prerequisites for data normality in the regression model in this study have been met. The calculation result of linearity test is shown in Table 5. 
Kholid, Su'ad, dan Achmad Hilal Madjdi

ANALYSIS OF PRINCIPAL'S ACADEMIC SUPERVISION AND TEACHER'S WORK ...

REFLEKSI EDUKATIKA : Jurnal Ilmiah Kependidikan, Volume 10, Nomor 2, Juni 2020, hlm. 257-266

Table 5. The Calculation Result of Linearity Test

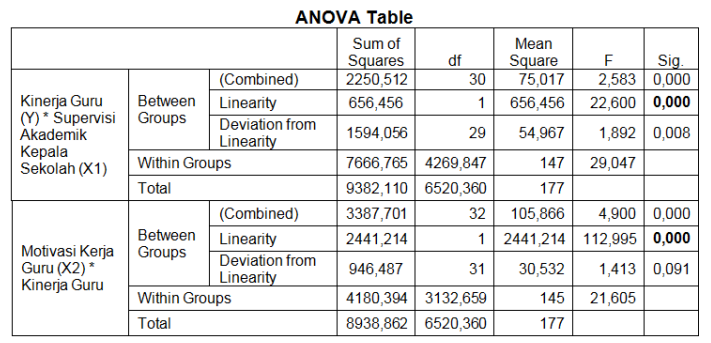

The linearity value in the significance column (Sig.) shows a value $<0.05$. Thus, prerequisites for data linearity in the regression model in this study have been met. Both, normality and linearity values have been met the requirement of the prerequisite analysis so that data can be used in regression analysis, both partial regression analysis, and multiple regression analysis and hypothesis testing.

\section{Analysis of the Principal's Academic Supervision toward Teacher Performance \\ The correlation level of principals' academic supervision toward teacher performance is shown in Table 6.}

Table 6. The Correlation Level Analysis of the Principal's Academic Supervision toward Teacher Performance

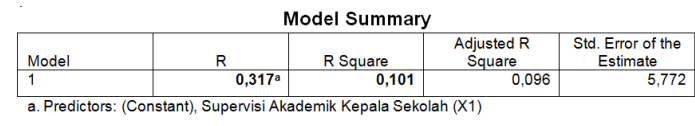

The correlation level of principals' academic supervision toward teacher performance was calculated to be $r=0.317$ categorized low with a magnitude of influence of $10.10 \%$ on teacher performance improvement. The calculation results of partial regression analysis and t-test of the principal's academic supervision toward teacher performance are known from the Coefficients Table of the following SPSS result, shown in Table 7.

Table 7. The Calculation Result of Partial Regression Analysis and t-test of the Principal's Academic Supervision toward Teacher Performance

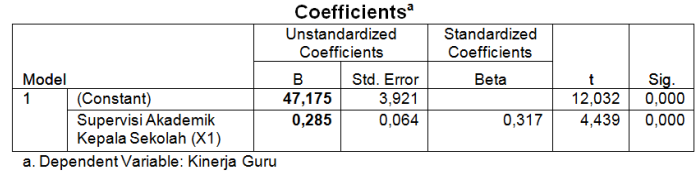

The effect of the principal's academic supervision toward teacher performance appears on the results of the regression formula $\mathrm{Y}=47.175+0.285 \mathrm{X}$ has a positive $\mathrm{X}$ coefficient of 0.285 which indicates that an increase in the principal's academic supervision can improve teacher performance. T-test results proved the t-value of $4.439>\mathrm{t}$-table of 1.97346 so the principal's academic supervision was proved to affect the performance of state elementary school teachers in Undaan District, Kudus Regency.

These results were supported by the results of interviews stating that the principal's academic supervision affected teacher performance improvement. The influence of the principal's academic supervision on improving teacher performance was also shown in several studies (Suhayati, 2013; Mahendri et al., 2013; Hasanah, 2014; Supardi et al., 2017). Thus, it can be stated that it is true that the principal's academic supervision has proven to have an effect on teacher performance, while the difference is only found in the magnitude of the effect.

The success of academic supervision activities depend on the principal's ability to plan, implement, monitor, and follow up/evaluate the academic supervision program. The preparation of academic supervision usually starts at the beginning of each learning year based on the results of follow-up on the implementation of the previous year, referring to the guidelines compiled by the Department of Education (Suraiya et al., 2016).

The main inhibiting factors that arose were principal's supervising competencies that were not yet maximal and the discrepancy in the schedule often occurred because of other more urgent service activities since most of the teachers are civil servants. Teacher readiness in conducting academic supervision activities and complete administration can ease the implementation of academic supervision (Nurohiman, 2016). The principal also needs to plan various academic supervision techniques, in case there are obstacles that cause changes in conditions, the principal can apply various alternative supervision techniques so that academic supervision activities are not disturbed (Izhar, 2017). Sometimes, academic supervision can also be done through assessments from peers that are carried out by senior teachers, have the necessary 
Kholid, Su'ad, dan Achmad Hilal Madjdi

ANALYSIS OF PRINCIPAL'S ACADEMIC SUPERVISION AND TEACHER'S WORK ...

REFLEKSI EDUKATIKA : Jurnal Ilmiah Kependidikan, Volume 10, Nomor 2, Juni 2020, hlm. 257-266

competence, and are appointed by the school principal to assist in academic supervision activities (Anissyahmai, 2016). Overall, academic supervision activities are one of the quality controls for teacher performance in schools. The quality of performance shown by the teacher needs to be regularly supervised to find out as soon as possible any deficiencies and can be corrected immediately. Professional and qualified teacher performance ensures the learning process runs optimally and produces competitive graduates (Mahendri et al., 2013).

\section{Analysis of the Teacher's Work Motivation toward Teacher Performance}

The correlation level of teacher's work motivation toward teacher performance is shown in Table 8.

Table 8. The Correlation Level Analysis of the Teacher's Work Motivation toward Teacher Performance

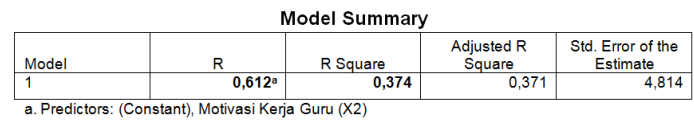

The correlation level of teacher's work motivation toward teacher performance was calculated to be $r=0.612$ categorized low with a magnitude of influence of $37.40 \%$ on teacher performance improvement. The calculation results of partial regression analysis and t-test of the teacher's work motivation toward teacher performance are known from the Coefficients Table of the following SPSS result, shown in Table 9.

Table 9. The Calculation Result of Partial Regression Analysis and t-test of the Teacher's Work Motivation toward Teacher Performance

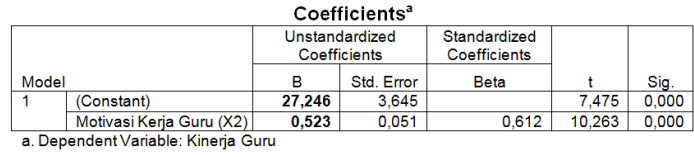

The effect teacher's work motivation of toward teacher performance also appears on the results of the regression formula $\mathrm{Y}=27.246+$ $0.523 \mathrm{X}$ has a positive $\mathrm{X}$ coefficient of 0.523 which indicates that an increase in the teacher's work motivation can improve teacher performance. T-test results proved the t-value of $10.263>\mathrm{t}$-table of 1.97346 so the teacher's work motivation was proved to affect the performance of state elementary school teachers in Undaan District, Kudus Regency.

These results were supported by the results of interviews stating that the teacher's work motivation affected teacher performance improvement. The influence of the teacher's work motivation on improving teacher performance was also shown in several studies (Saputra et al., 2015; Sumarsih, 2016). Thus, it can be stated that it is true that the teacher's work motivation has proven to have an effect on teacher performance, while the difference is only found in the magnitude of the effect.

The teacher's work motivation appears through the responsibility of carrying out the task. The teacher's sense of responsibility in learning can be realized in the teacher's attitude in preparing all learning needs. Teachers who are motivated by a sense of responsibility will think about and consider the learning methods to be applied, the media used, to the technical assessment in evaluating student learning outcomes. Maximum learning preparation is one of the factors supporting the success of student learning as well as including one aspect in Teacher Performance Assessment (Nasution, 2016; Nurmalina, 2016; Uno, 2016). Teachers who work hard to achieve certain achievements will show maximum performance. The desire of teachers to excel will form a determination that arises from within the teacher to work harder. Work achievements give teachers enthusiasm for working and develop teacher creativity in carrying out their duties. Teachers who excel also have the potential to get awards, accelerate career advancement, and improve well-being. These things can also add even greater motivation so that teachers can provide maximum performance (Sormin, 2019).

Analysis of the Principal's Academic Supervision and Teacher's Work Motivation toward Teacher Performance

The correlation level of principals' academic supervision and teacher's work motivation toward teacher performance is shown in Table 10. 
Kholid, Su'ad, dan Achmad Hilal Madjdi

ANALYSIS OF PRINCIPAL'S ACADEMIC SUPERVISION AND TEACHER'S WORK ...

REFLEKSI EDUKATIKA : Jurnal Ilmiah Kependidikan, Volume 10, Nomor 2, Juni 2020, hlm. 257-266

Table 10. The Correlation Level Analysis of the Principal's Academic Supervision and Teacher's Work Motivation toward Teacher Performance

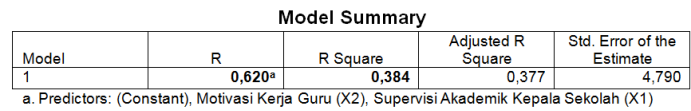

The correlation level of principals' academic supervision and teacher's work motivation toward teacher performance was calculated to be $\mathrm{R}=0.620$ categorized low with a magnitude of influence of $38.40 \%$ on teacher performance improvement. The multiple regression analysis of the principal's academic supervision and teacher's work motivation toward teacher performance is known from the Coefficients Table of the following SPSS result, shown in Table 11.

Table 11. The Multiple Regression Analysis of the Principal's Academic Supervision and Teacher's Work Motivation toward Teacher Performance

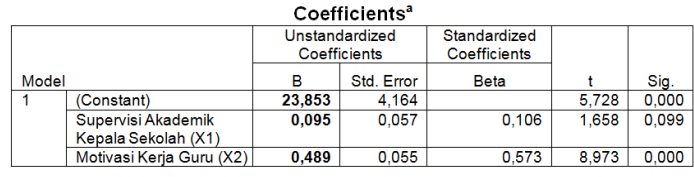

The effect of the principal's academic supervision and teacher's work motivation toward teacher performance appears on the results of the regression formula $\mathrm{Y}=23.853+$ $0.095 \mathrm{X}_{1}+0.489 \mathrm{X}_{2}$ has a positive $\mathrm{X}_{1}$ and $\mathrm{X}_{2}$ coefficient of 0.095 and 0.489 , respectively which indicates that an increase in the principal's academic supervision and teacher's work motivation can improve teacher performance. The calculation results of F-test of the principal's academic supervision and teacher's work motivation toward teacher performance are known from the ANOVA Table of the following SPSS result, shown in Table 12.

Table 12. The Calculation Result of Partial Regression Analysis and t-test of the Principal's Academic Supervision toward Teacher Performance

\begin{tabular}{|c|c|c|c|c|c|c|}
\hline \multicolumn{7}{|c|}{ ANOVA $^{a}$} \\
\hline \multicolumn{2}{|c|}{ Model } & $\begin{array}{l}\text { Sum of } \\
\text { Squares }\end{array}$ & $d f$ & Mean Square & $\mathrm{F}$ & Sig. \\
\hline \multirow[t]{3}{*}{1} & Regression & 2504,306 & 2 & 1252,153 & 54,563 & $.000^{6}$ \\
\hline & Residual & 4016,054 & 175 & 22,949 & & \\
\hline & Total & 6520,360 & 177 & & & \\
\hline
\end{tabular}

F-test results proved the F-value of $54.563>$ F-table of 3.05 so the principal's academic supervision and teacher's work motivation were proved to affect the performance of state elementary school teachers in Undaan District, Kudus Regency.

These results were supported by the results of interviews stating that the principal's academic supervision and teacher's work motivation affected teacher performance improvement. The influence of the principal's academic supervision and teacher's work motivation on improving teacher performance was also shown in several studies (Ismaya, 2013, Anggriani, 2010; Kadis, 2015, Sudrajat et al., 2015; Fransiska et al., 2017, Iswan dan Hadidah, 2019). Thus, it can be stated that it is true that the principal's academic supervision and teacher's work motivation have proven to have an effect on teacher performance, while the difference is only found in the magnitude of the effect.

This study, generally, has some similarities and differences with several studies. Zalwango (2014) shows that teacher performance is in a good category even though work motivation is not optimal. This study found various other factors that influence performance such as discipline and good teacher morale. However, in this study, it is also known that the motivation and performance of teachers can be improved by increasing compensation in the form of salaries based on living standards, recognition of good performance, and improvement of teaching facilities.

Amina (2015) also found that supervision by the principal could improve teacher performance. In addition, the improvement in teacher performance is also influenced by the involvement of teachers in school decision making. The supervision of the school principal and the involvement of the teacher in school decision making is known to also be able to bring the relationship between the teacher and the headmaster personally.

Rismawan (2015), Renata et al (2018) and Sudarjat et al (2015) specifically examined the principals' supervision, teacher achievement motivation, and teacher teaching performance. Thus, an increase in the supervision skills of principals and achievement motivation can increase the effectiveness of teachers in carrying out their 
Kholid, Su'ad, dan Achmad Hilal Madjdi

ANALYSIS OF PRINCIPAL'S ACADEMIC SUPERVISION AND TEACHER'S WORK ...

REFLEKSI EDUKATIKA : Jurnal Ilmiah Kependidikan, Volume 10, Nomor 2, Juni 2020, hlm. 257-266

duties and responsibilities. Emgiek et al (2018) focused on managerial supervision, teacher competence, achievement motivation that influence teacher performance partially and simultaneously.

Meanwhile, as the difference, this study was more focused on analyzing the relationship between the completeness of the principal's academic supervision program and the conditions of teacher's work motivation toward teacher performance based on teacher work achievement in implementing the learning process.

\section{CONCLUSIONS}

Principal's academic supervision has a significant effect on the performance of state elementary school teachers in Undaan District, Kudus Regency. The correlation coefficient value of 0.317 shows the academic supervision of the principal has a low relationship with teacher performance. The influence of the principal's academic supervision on teacher performance by $10.10 \%$, while the remaining $89.90 \%$ was influenced by other factors.

Teacher's work motivation has a significant effect on the performance of state elementary school teachers in Undaan District, Kudus Regency. Correlation coefficient value of 0.612 indicates teacher work motivation has a strong relationship to teacher performance. The influence of teacher's work motivation on teacher performance by $37.40 \%$, while the remaining $62.60 \%$ was influenced by other factors.

Principal's academic supervision and teacher's work motivation have a significant effect on the performance of state elementary school teachers in Undaan District, Kudus Regency. Correlation coefficient value of 0.620 shows the principal's academic supervision and teacher's work motivation has a strong relationship with teacher performance. The influence of the principal's academic supervision and teacher's work motivation on teacher performance by $38.40 \%$, while the remaining $61.60 \%$ was influenced by other factors.

\section{REFERENCES}

Amina, J. A. 2015. An Evaluation of Head teachers Performance in Supervision of Instruction and Involvement of Staff in
Decision-Making in the School. International Journal of Research in Humanities and Social Studies, 2 (7): 129-142.

Angriani, N. 2010. Kontribusi Supervisi Kepala Sekolah Dan Motivasi Kerja Guru Terhadap Kinerja Mengajar Guru (Pada Sman Se-kabupaten Indragiri Hulu Propinsi Riau). Jurnal Administrasi Pendidikan UPI, 12 (1): 15.

Anissyahmai. 2016. Supervisi Akademik Kepala Sekolah. Manajer Pendidikan, 10 (3): 314-321.

Emgiek, R. A., Sutarto, J., dan Prihatin, T. 2018. The Effect of Managerial Supervision on School Supervisors, Competence, and Achievement Motivation on The Performance of Primary School Principals at The Dikbud Office Kec. Adiwerna Kab. Tegal. Educational Management, 7 (1): 46-51.

Fransiska, Wahyudi, dan Suib, M. 2017. Kontribusi Supervisi Akademik Kepala Sekolah dan Motivasi Kerja Guru terhadap Kinerja Mengajar Guru. Jurnal Pendidikan dan Pembelajaran Katulistiwa, 6 (6): 1-14.

Hasanah, U. U. 2014. Pengaruh Supervisi Akademik dan Kegiatan Kelompok Kerja Guru terhadap Kinerja Mengajar Guru. Jurnal Adminisistrasi Pendidikan UPI, 21 (2): 123-135.

Hasibuan, M. S. P. 2014. Organisasi dan Motivasi Dasar Peningkatan Produktivitas. Jakarta: Bumi Aksara.

Iroegbu, E. E. dan Etudor-Eyo, E. 2016. Principals' Instructional Supervision and Teachers' Effectiveness. British Journal of Education, 4 (7): 99-109.

Ismaya, Erik Aditia. 2013. Guru Yang Cerdas Dan Santun, Profil Guru Profesional Dan Berkarakter Lulusan Universitas Muria Kudus. Prosiding Seminar Nasional yang Peranan Guru Profesional dan 
Kholid, Su'ad, dan Achmad Hilal Madjdi

ANALYSIS OF PRINCIPAL'S ACADEMIC SUPERVISION AND TEACHER'S WORK ...

REFLEKSI EDUKATIKA : Jurnal Ilmiah Kependidikan, Volume 10, Nomor 2, Juni 2020, hlm. 257-266

Berkarakter dalam Pembangunan Sumber Daya Manusia di Era Global PGSD Universitas Muria Kudus 30 Maret 2013, 96-106.

Iswan, dan Hadidah, Indah. 2019. Pengaruh Disiplin Kerja Guru Terhadap Disiplin Belajar Siswa Sekolah Dasar. Refleksi Edukatika : Jurnal Ilmiah Kependidikan, 10 (1): 121-127.

Izhar, M. 2017. Supervisi Akademik Kepala Sekolah dalam Meningkatkan Kinerja Mengajar Guru. Manajer Pendidikan, 11 (1): 97-105.

Kadis. 2015. Peningkatan Kemampuan Guru Dalam Pengelolaan Pembelajaran Tematik Saintifik Melalui Supervisi Klinis Pendekatan Humanistik Teknik Implant Bagi Guru Kelas Iv Dabin I Gugus "Sukarno-Hatta" Dinas Pendidikan Kecamatan Gabus Kabupaten Pati Pada Semester I Tahun Pelajaran 2014/2015. Refleksi Edukatika : Jurnal Ilmiah Kependidikan, 5 (1).

Madjid, A. 2016. Pengembangan Kinerja Guru Melalui: Kompetensi, Komitmen dan Motivasi Kerja. Yogyakarta: Samudra Biru.

Mahendri, K. D. A., Suhandana, G. A., dan Suarni, N. K. 2013. Determinasi Gaya Kepemimpinan Kepala Sekolah, Disiplin Kerja, dan Supervisi Akademik terhadap Kinerja Guru di Sekolah Dasar Negeri Se-Gugus 3 Kecamatan Kuta Utara Kabupaten Badung. Jurnal Administrasi Pendidikan UNDIKSHA, 4 (1): 1-11.

Nasution, S. P. 2016. Peranan Kepala Madrasah terhadap Kinerja Guru. AlIradah: Jurnal Kependidikan Islam, 6 (1), 190-209.

Nurmalina. 2016. Disiplin dan Motivasi Kerja Guru Mempengaruhi Prestasi Belajar Siswa. Jurnal As-Salam, 1 (1), 83-95.

Nurohiman. 2016. Supervisi Akademik oleh Kepala Sekolah dalam Meningkatkan
Kinerja Guru. Manajer Pendidikan, 10 (6): 608-615.

Nyam, J. dan William-west, T. O. 2014. Teachers Motivation: A Study of the Psychological and Social Factors. International Journal of Education and Research, 2 (2): 1-8.

Renata, Wardiah, D., dan Kristiawan, M. 2018. The Influence of Headmaster's Supervision and Achievement Motivation on Effective Teachers. International Journal of Scientific and Technology Research, 7 (6): 44-49.

Rismawan, E. 2015. Pengaruh Supervisi Kepala Sekolah dan Motivasi Berprestasi Guru terhadap Kinerja Mengajar Guru . Jurnal Administrasi Pendidikan, 22 (1): 114-132.

Saputra, E., Sumadi, dan Miswar, D. 2015. Pengaruh Gaya Kepemimpinan Kepala Sekolah dan Motivasi Kerja Guru terhadap Kinerja Guru. Jurnal Penelitian Geografi UNILA, 3 (3): 1-12.

Sormin, N. 2019. Upaya Meningkatkan Prestasi Kerja Guru melalui Peran Pembinaan Kepala Sekolah di SDN 3 Selat Tengah Kecamatan Selat Kabupaten Kapuas. Jurnal Pendidikan Ilmu Pengetahuan Sosial, 11 (1): 53-67.

Sudarjat, J., Abdullah, T., dan Sunaryo, W. 2015. Supervision, Leadership, and Working Motivation to Teachers' Performance. International Journal of Managerial Studies and Research, 3 (6): 146-152.

Suhayati, I. Y. 2013. Supervisi Akademik Kepala Sekolah, Budaya Sekolah, dan Kinerja Mengajar Guru. Jurnal Adminisistrasi Pendidikan UPI, 17 (1): 86-95.

Sulisworo, D., Nasir, R., dan Maryani, I. 2017. Identification of Teachers' Problems in Indonesia on Facing Global Community. International Journal of Research Studies in Education, 6 (2): 81-90. 
Sumarsih. 2016. Pengaruh Motivasi Kerja dan Kompetensi Profesional terhadap Kinerja Guru Sekolah Dasar di Kecamatan Cikarang Utara, Kabupaten Bekasi. Jurnal Pendidikan Dasar UNJ, 7 (2): 361-374.

Supardi, I., Chair, M., dan Wahyudi. 2017. Pengaruh Supervisi Akademik dan Kepemimpinan Situasional Kepala Sekolah terhadap Kinerja Guru SMP Negeri Sambas. Jurnal Pendidikan dan Pembelajaran Katulistiwa, 6 (1): 1-16.

Suraiya, Usman, N., dan Ar, D. 2016. Pelaksanaan Supervisi Akademik oleh Kepala Sekolah dalam Meningkatkan Kompetensi Profesional Guru pada SD Negeri Lam Ura Kecamatan Simpang Tiga Kabupaten Aceh Besar. Jurnal Administrasi Pendidikan Pascasarjana Universitas Syiah Kuala, 4 (1): 148157.
Ugurlu, C. T. 2014. Current Problems in Terms of Supervision Process of School Principals' Views. Hacettepe Universitesi Journal of Education, 29 (3): 184-196.

Uno, H. B. 2016. Teori Motivasi dan Pengukurannya: Analisis di Bidang Pendidikan. Jakarta: Bumi Aksara.

Yousaf, S. U., Usman, B., dan Islam, T. 2018. Effects of Supervision Practices of Principals on Work Performance and Growth of Primary School Teachers. Bulletin of Education and Research, 40 (1): 285-298.

Zalwango, M. 2014. The Role of Motivation in Enhancing Teachers' Performance in Private Primary Schools: a Case of st. Mary's International Schools. Disertasi Tazania: Open University of Tanzania. 